M. Yu. Syzyi

State Institution «V. T. Zaitsev

Institute of General and

Emergency Surgery of NAMS of

Ukraine», Kharkiv

(C) Syzyi M. Yu

DOI:https://doi.org/10.37699/2308-7005.3-4.2019.28

\section{TREATMENT-DIAGNOSTIC MEASURES FOR INJURY OF THE NECK}

Summary. The article is devoted to the study of the urgent problem of neck injury and medical diagnostic tactics. Externally, a small wound on the neck can hide serious damage to deep structures and adjacent anatomical areas. In peacetime during neck injuries, it is necessary stick to the basic principles of surgery: all wounds are subject to primary surgical treatment with a thorough revision of the wound canal. The algorithm of therapeutic and diagnostic measures depends on the nature and severity of the damage, clinical symptoms, and related injuries that are life-threatening.

Keywords: neck wound, surgical approach, diagnostic and treatment activities.

\section{Introduction}

Penetrating neck injuries due to its complex topographic and anatomical features are among the most insidious. They are often characterized by the severe condition of the victims, the variability of the clinical course, the unpredictability of the course of the wound canal and damaged organs, as well as the need for urgent surgery $[1,3,5,6,9]$. From 10,0 to $33,0 \%$ of all wounds of the neck are accompanied by damage to the main vessels, the mortality rate for such injuries ranges from 3,0 to $30,0 \%[1,6,10]$. The apparent ease of trauma in neck injuries is one of the causes of diagnostic and tactical errors. Even with the surgical treatment of such wounds, gross diagnostic and tactical errors can be tolerated [8].

\section{Aim}

Analysis of results of surgical treatment of the victims with injuries of the neck and development of rational surgical tactics with such injuries.

\section{Materials and methods}

From 2009 to 2019 in «V.T. Zaytseva Institution of General and Emergency Surgery of NAMS of Ukraine» treated 174 patients with neck injuries between the ages of 15 and 64 (151 men and 23 women). Puncture-cut wounds were observed in $162(93,1 \%)$, gunshot wounds in 12 patients $(6,9 \%)$. The vast majority of patients were intoxicated. Multiple wounds were noted in 13 traumatized (7,9\%), combined knife injuries of other anatomical areas - in $27(15,5 \%)$. In 3 patients neck injuries were combined with severe traumatic brain injury.

\section{Results and discussion}

Surgery of gunshot and knife wounds of vital anatomical areas today has emerged as an independent area of emergency surgery other than traumatology. The basic principles of assisting the injured neck are the provisions of military surgery, taking into account the peculiarities of the specific situation and conditions for the organization of surgical care in the region and this medical institution.

The first condition that gives hope for a successful result in severe injuries to the neck is the timely delivery of the victim to the multidisciplinary medical institutions and resuscitation during transportation. The importance of the pre-hospital stage in assisting the victims with neck injuries is evidenced by the results of their long-term observations.

During the transport, the SMD 38 injured patients underwent intensive care. Given the blood loss and the condition of the victim, it consisted in the transfusion of polyglucine and crystalloids, the introduction of cardiovascular agents, hormones. In 15 cases the subclavian vein was catheterized, in 12 - the tracheal intubation was performed. The gravity of the condition of the victims was evidenced by the fact that 39 patients upon admission to the hospital had hemorrhagic shock of varying severity.

The algorithm of treatment and diagnostic measures and the sequence of use of different methods of examination depend on the nature and severity of the injury, clinical symptoms and associated injuries that are life-threatening. For practical purposes in the diagnosis and assessment of patients with neck injuries to determine surgical tactics were divided into 2 groups: 1 group - patients with severe injuries, signs of prolonged intense bleeding from the wound, severe hemodynamic disorders and respiratory disorders; Group 2 - patients with mild or moderate severity of wounds who had stable hemodynamics and / or no respiratory disorders, signs of bleeding.

The first group consisted of 55 people (31,5\%) with stab-cut and gunshot wounds of the main vessels of the neck, damage to the trachea, wounds penetrating the mediastinum and chest cavity. Indications for delivery directly to the operating room were massive bleeding from the wound (26), a threatening hematoma around the wound (8), an episode of massive bleeding from the wound at the scene from the words of health workers or accompanying persons (2), respiratory disorders (18), hemopneumothorax (1). 
Due to the need for urgent surgical intervention in this group of patients, the time for medical-diagnostic measures was minimized. In the course of preparation for surgery and introduction to anesthesia, the patient's condition, the nature of the wound, the location of the inlet and outlet openings, the presence of subcutaneous emphysema were evaluated - physical methods of diagnosis were used. 6 patients underwent ultrasonography of the heart, abdominal cavity and pleural cavity, 6 pleural puncture, 1 patient performed a drainage of the pleural cavity by Bulau and reinfusion of $800 \mathrm{ml}$ of blood.

At tracheal intubation all patients underwent laryngoscopy. Tracheo-bronchoscopy and rehabilitation of a bronchial tree were performed in 6 of the wounded. When gastric drainage, the probe paid attention to the presence of blood in the esophagus. During surgery, 6 patients in group 1 had to undergo esophagoscopy. The esophageal lesions are endoscopically established in 2 patients, the pharyngeal wounds in 2 .

The second group of patients was represented by 119 victims $(68,5 \%)$. The condition of these traumas allowed to make an in-depth examination under conditions of waiting room or diagnostic department. The algorithm of therapeutic and diagnostic measures in this group of patients was extended. According to the testimony, 12 were performed craniography, 36 - radiography of the lungs, 3 - radiography of the spine, 17 - esophagoscopy, 12 - echoencephalography, 37 - ultrasound examination of abdominal organs, 1 - angiography.

All patients were operated on. In the initial surgical treatment of the wound in 5 cases, the wound was impenetrable. For rapid hemostasis and revision of vital deep neck structures, standard Razumovsky access was used by a longitudinal colotomy at the leading edge of $\mathrm{m}$. sternocleidomastoideus on the side of the wound.

Of the 169 wounded with penetrating wounds, 55 $(32,5 \%)$ were diagnosed with damage to the main vessels. Six of the victims suffered multiple lesions: common carotid artery and internal jugular vein (2), facial and thyroid arteries (1), both external jugular veins (1), external and internal jugular veins (2). The pervasive gunshot wound of the internal jugular vein was diagnosed in 1 follow-up. In the case of injuries of the main vessels of the neck, preference was given to restorative operations.

Temporary hemostasis with continued bleeding was performed with a finger

pressing. The ends of the damaged vessel were mobilized, they were taken on turnstiles, which allowed adequate control of blood loss. In the wounds of the common and internal carotid arteries, protection of the brain against ischemia was performed by controlled hypertension, systemic heparinization.

In the injury of the common carotid artery, the restoration of blood flow was achieved in two cases out of five by the imposition of a circular vascular suture, one by the use of an auto-venous insertion, one by prosthetics, and another by the imposition of a vascular suture. In one observation, with a lesion of the common carotid artery and the internal jugular vein, with blood loss of more than 3 liters, despite vascular ligation, death occurred on the operating table from hemorrhagic shock.

It is most difficult to stop bleeding in spinal artery injuries. Of the 4 victims with complete intersection of this vessel in the first segment, only one managed to have her bandaging using a Deschan needle. In 3 observations to isolate the spinal artery and stop the bleeding, the cancellation of 2-3 transverse processes of the cervical vertebrae was performed, followed by diathermocoagulation, muscle tamponade, and stitching of the bleeding source.

In the wounds of the internal jugular vein, 14 patients were placed vascular suture, and one made auto-venous plastic. In other cases, the blood vessels are bandaged.

Tracheal lesions were found in 10 people, in 3 of them they were end-to-end and were combined with wounds of the cervical esophagus. Because the operations were performed under intubation anesthesia, examination of the back wall of the esophagus was difficult. In the diagnosis of 2 patients, significant help was provided by the endoscopic examination before surgery, in 4 patients on the operating table. During intervention after intubation of the esophagus with a thick gastric tube, all patients suspected of his injury in the area of the paraesophageal hematoma were doing gentle mobilization and careful revision of this organ. In the presence of a wound, the integrity of the wall was restored by nodal nylon sutures. Five of the wounded were immediately given a gastrostomy, and in one case, two weeks were given probe feeding.

In 10 cases with damage to the trachea, the suturing was made in 9, tracheostomy overlay - in 1 case. Throat lesions were encountered in 14 observations. Wound suturing was performed, and further probe feeding.

Thyroid injury was detected in 7 observations, parotid gland in 3. All patients underwent suturing of the parenchyma of the glands.

Of 169 patients with penetrating neck injuries at 3 during the surgical treatment of the wound, mediastinal wounds were diagnosed. On the occasion of copious bleeding from the mediastinum one patient underwent a sternotomy. The audit revealed damage to the nameless artery extending from the aortic arch. The artery is bandaged. In two patients with anterior mediastinal injury and mediastinal hematoma, drainage was performed with silicone drainage.

Injury of the subclavian artery to the left was sutured from the cervical access after crossing the clavicle. In another case at a gunshot wound to the neck was diagnosed with left-sided hemothorax. Here, pleural cavities were drained prior to revision and $800 \mathrm{ml}$ of blood were reinfused. 
In total, 5 patients died, among the immediate causes of death were hemorrhagic shock (3), acute cerebral circulation disorders (1), and multiple organ failure (1).

Thus, 36,0 \% of patients with penetrating neck injuries are diagnosed with damage to large vessels, in some cases they are associated with damage to the pharynx, trachea, esophagus, mediastinum and breast.

In case of damage to the main vessels of the neck, an important factor, which increases the severity of the victims, is the timely provision of medical care at the pre-hospital stage and resuscitation measures during the transportation of the injured.

\section{Conclusions}

Active surgical tactics with careful revision of the wound canal, rational application of instrumental research methods to surgery, during surgery in the victims with injuries of the neck are absolutely justified. It allows you to diagnose damage to vital deep neck structures and adjacent anatomical areas in a timely manner, to conduct rational surgery, to prevent fatal complications and to improve treatment outcomes.

\section{REFERENCES}

1. Aladelusi T, Akinmoladun V, Olusanya A, Akadiri O, Fasola A. Analysis of Road Traffic Crashes-Related Maxillofacial Injuries Severity and Concomitant Injuries in 201 Patients Seen at the UCH, Ibadan. Craniomaxillofac Trauma Reconstr. 2014 Dec;7(4):284-9.

2. Alvi A, Doherty T, Lewen G. Facial fractures and concomitant injuries in trauma patients. Laryngoscope 2003 Jan;113(1):102-6.

3. Butvidas Lynn D. Disparities between resident and attending surgeon perceptions of intraoperative teaching [Text] / Lynn D. Butvidas, Cheryl I. Anderson, Daniel Balogh, Marc D. Basson //The American Journal of Surgery. - 2011. — Vol. 201, № 3. - P. 385-389.

4. Dosios T. Surgical treatment of esophageal perforation [Text] / T. Dosios, M. Safioleas, N. Xipolitas // Hepatogastroenterology. - 2003. - Vol. 50-52. - P. 1037-1040.

5. Hinojar A. G. Management of hypopharyngeal and cervical oesophageal perforations [Text] / A. G. Hinojar, M. A. Diaz
Diaz, Y. W. Pun, A. A. Hinojar // Auris. Nasus. Larynx. - 2003. - Vol. 30, № 2. - P. 175-182.

6. Katsetos M.C., Tagbo A.C., Lindberg, Rosson R.S. Esophageal perforation and mediastinitis from fish bone ingestion [Text] / M. C. Katsetos, A. C. Tagbo, M. P. Lindberg, R. S. Rosson // South. Med. J. — 2003. - Vol. 96, № 5. - P. 516-520.

7. Larynx, hypopharynx and mandible injury due to external penetrating neck injury [Text] / D. Acar, M. Tekin, O. H. Cam, E. Kaytancı // Ulus Travma Acil. Cerrahi. Derg. - 2013. - Vol. 19, N. 3. - P. 271-273.

8. McKinlay J. Penetrating brain injury: a case of survival following blast fragmen-tation injuries to the head [Text] / J. McKinlay, J.E. Smith // J.R. Nav. Med. Serv. - 2013. - Vol. 99, N. 2. - P. 55-56.

9. Mussi A. Acute major airway injuries: clinical features and management [Text] / A. Mussi, M. C. Ambrogi, A. Ribechini et al. //Eur. J. Cardiothorac. Surg. - 2001. - Vol. 20. - P. 46-52.
ЛІКУВАЛЬНО-

ДІАГНОСТИЧНІ ЗАХОДИ ПРИ УШКОДЖЕННІ ШИЇ

\section{М. Ю. Сизий}

Резюме. Статтю присвячено вивченню актуальної проблеми поранення шиї та лікувально-діагностичної тактики. Зовні невелика рана на шиї може приховувати в собі серйозні пошкодження глибоких структур і суміжних анатомічних областей. В умовах мирного часу при пораненнях шиї необхідно дотримуватися принципів базової хірургії: всі рани підлягають первинній хірургічній обробці з ретельною ревізією ранового каналу. Алгоритм лікувально-діагностичних заходів залежать від характеру і тяжкості ушкодження, клінічних симптомів, супутніх ушкоджень, які представляють небезпека для життя.

Ключові слова: поранення шиї, хірургічна тактика, лікувальнодіагностичні заходи.

Резюме. Статья посвящена изучению актуальной проблемы ранения шеи и лечебно-диагностической тактики. Внешне небольшая рана на шее может скрывать в себе серьезные повреждения глубоких структур и смежных анатомических областей. В условиях мирного времени при ранениях шеи необходимо придерживаться базовых принципов хирургии: все раны подлежат первичной хирургической обработке с тщательной ревизией раневого канала. Алгоритм лечебно-диагностических мероприятий зависит от характера и тяжести повреждения, клинических симптомов, сопутствующих повреждений, представляющих опасность для жизни.

Ключевые слова: ранения шеи, хирургическая тактика, лечебнодиагностические мероприятия. 